\title{
Compilation of regional financial balances for the 'General Governance' sector in the Ural Federal District
}

\author{
A.F. Pasynkov \\ Institute of Economics of the Ural Branch of the Russian Academy of Sciences, Ekaterinburg, Russia; monografia@mail.ru
}

\begin{abstract}
Relevance. In recent years, the significance of financial flows in the public sector in territorial development in Russia has been growing. To be able to analyze all public sector revenues and expenditures at the regional level, it is necessary to develop financial balances that take into account all flows of financial resources. Research objective. The purpose of this study is to create financial balances of the 'General Governance' sector by using the example of six regions in the Ural Federal District. Data and methods. The study is based on the theoretical framework of the System of National Accounts. The author proposes a methodological approach to the consolidation of official statistical reports from open sources in accordance with the classification of government revenues and expenditures in national accounting. Results. The proposed methodology for calculating the income and expenditures of all budgets in the region, including the volume of direct federal expenditures, is based on comparing the data on the sources of added value formation. A database on income and expenditures of the regions of the Ural Federal District for the period 2014-2018 was made and a matrix of financial balances of the 'General Governance' sector by regions for 2017 was built. To this end, the structure and amount of public institutions financing costs were specified and donor and recipient regions of the Ural Federal District were identified. Conclusions. Financial resources of the public sector affect the economy of the regions of the Ural Federal District in several ways. The regions specializing on oil and gas production are net donors to the sector, the rest of the regions cannot provide for themselves and are more dependent on federal funds. The sector 'General Governance' generates more than 10\% of GRP of Chelyabinsk and Sverdlovsk regions and more than $20 \%$ of Kurgan region. The results can be used for planning and forecasting of socio-economic development of certain areas.
\end{abstract}

\section{KEYWORDS}

gross value added, institutional sectors, system of national accounts, public administration, Russian regions, Ural Federal District

\section{ACKNOWLEDGEMENTS}

The study is supported by the Russian Foundation for Basic Research, project 18-010-01001 'Sector "General Government": The Formation of Financial Balances of Regions and Municipalities on the Basis of the Principles of the System of National Accounts'.

\section{FOR CITATION}

Pasynkov, A.F. (2020) Compilation of regional financial balances for the 'General Governance' sector in the Ural Federal District. R-economy, 6(4), 251-260. doi: 10.15826/recon.2020.6.4.022

\section{Формирование финансовых балансов сектора «государственное управление» субъектов РФ (на примере регионов Уральского федерального округа)}

\author{
А.Ф. Пасынков \\ Институт экономики Уральского отделения Российской академии наук, Екатеринбург, Россия; \\ monografia@mail.ru
}

\begin{abstract}
АННОТАЦИЯ
Актуальность. В последние годы в Российской Федерации все возрастающее значение на развитие территорий оказывают влияние финансовые потоки органов государственного управления. Для полного отражения всех доходов и расходов государственного сектора на региональном уровне, необходимо разработка финансовых балансов, которые позволяют учитывать все потоки финансовых ресурсов. Цель исследования. Целью настоящего исследования выступает формирование финансовых балансов сектора «Государственное управление» на примере шести субъектов федерации, входящих в Уральский федеральный округ. Данные и методы. Исследование базируется на теоретических положениях формирования Системы национальных счетов и авторском методологическом подходе к консолидации официальной статистической отчетности из открытых источников, которая соответствует принятой в национальном счетоводстве классифи(c) Pasynkov, A.F., 2020
\end{abstract}

\section{КЛЮЧЕВЫЕ СЛОВА} валовая добавленная стоимость, институциональные сектора, система национальных счетов, государственное управление, субъект РФ, Уральский федеральный округ 
кацией доходов и расходов органов государственного управления. Результаты. Разработана методика расчета доходов и расходов всех бюджетов на территории региона, в том числе объема прямых федеральных расходов на территориях субъекта федерации, через сопоставление данных по источникам формирования добавленной стоимости. На этой основе была сформирована база данных по доходам и расходам регионов Уральского Федерального округа за период 2014- 2018 гг. и построена матрица финансовых балансов сектора «Государственное управление» по субъектам РФ за 2017 г. Выделена структура и объем расходов финансирования государственных заведений, определены территории доноры и реципиенты Уральского федерального округа. Выводы. Финансовые ресурсы государственного сектора оказывают влияние на экономику регионов УрФО разнонаправлено. Нефтегазодобывающие территории являются чистыми донорами сектора, остальные регионы не могут обеспечить себя финансовыми ресурсами, с учетом федеральных расходов. Сектор «Государственное управление» формирует более $10 \%$ регионального продукта Челябинской и Свердловской областей и более $20 \%$ Курганской области. Полученные результаты могут быть использованы при планировании и прогнозировании социально-экономического развития отдельных территорий.

\section{БЛАГОДАРНОСТИ}

Работа поддержана Российским фондом фундаментальных исследований, проект 18-01001001 «Сектор “государственное управление»: формирование финансовых балансов регионов и муниципальных образований на основе принципов системы национальных счетов».

\section{ДЛЯ ЦИТИРОВАНИЯ}

Pasynkov, A.F. (2020) Compilation of regional financial balances for the 'General Governance' sector in the Ural Federal District. R-economy, 6(4), 251-260. doi: $10.15826 /$ recon.2020.6.4.022

\section{Introduction}

Socio-economic development of territories at various levels depends on many different factors that influence the level and dynamics of reproduction processes. The driving force of any economy is the sector of production of goods and services, which creates the added value of the territory. Financial resources generated by the manufacturing sector are a source of income for people and regional governments, forming the tax base of the territories. On the other hand, the expenditures of households and budgets of all levels provide the demand for goods in the production sector, ensuring the circulation of financial flows in regions.

Recently, a general trend for Russia and the world in general has been the increasing importance of financial flows in the public sector for the development of territories. The importance of the general government sector in the circulation of financial flows lies in the redistribution of added value between economic units and territories, which allows to solve certain problems, including the equalization of conditions for socio-economic development. Therefore, for various territories, financial flows of the public sector are of different importance, both in the structure of value added and in the ratio of revenues and expenditures of the general government sector.

However, studies of the financial balances of territories are limited to the generalization and analysis of the data on collected tax payments and consolidated budgets of the regions. Therefore, it is impossible to draw conclusions about the degree of dependence of regional economy on budget flows. At the same time, financial balances of public administration imply accounting for all resource flows, regardless of the level and direction of their movement. It is this approach that is incorporated in the concept of building an international system for assessing economic activity the System of National Accounts.

The System of National Accounts (SNA) is an internationally agreed standard set of guidelines for calculating indicators of economic activity in accordance with clear rules for maintaining accounts at the macro level, based on the principles of economic theory. Without going into details, it can be noted that the main resulting account indicator, often used by researchers, economists and government officials, is Gross Domestic Product (GDP). At the same time, the SNA consists of a large number of accounts and classifications that make it possible to assess the proportions and patterns of economic development of a particular territory. For the regional and municipal level, the author proposes to develop an analogue of such a system - territorial accounts.

In this regard, the formation of financial balances of the 'General Governance' sector in Russian regions makes it possible to assess the movement of funds of budgets of all levels and determine the outflow / inflow of resources in certain territories. Therefore, the main purpose of this study is the creation of financial balances of the 'General Governance' sector by using the example of six regions of the Ural Federal District. The goals of the study are as follows: to determine the total flow of tax payments by regions to the budgetary system of Russia; to allocate regional budgetary expenditures in the SNA classification; 
to calculate the federal part of expenditures in GRP of the regions of the Ural Federal District; and determine donor and recipient regions in accordance with the 'General Governance' sector.

\section{Theoretical framework}

From the theoretical point of view, the problem of assessing the income and expenditures of territories at the level of both regions and individual municipalities has been considered in Russian science for a long time. A significant part of the research is devoted to assessing the balance of budgets, the ratio of territories' own revenues and transfers, the level of subsidization of territories, etc.

In this regard, a lot of works have been devoted to the balances of income and expenditures of regional (municipal) budgets. For example, Khapsaeva (2014) examines the theoretical aspects of balancing regional budgets. Zhuravleva (2015) focuses on the case of Ukraine and defines the role of tax revenues in the regional budget system, highlighting approaches to the formation of a balanced municipal budget (Bogolib, 2015).

The influence of federal transfers and financial macroeconomic policy on the regional financial system is another widely discussed topic. For example, Istomina (2016), outlines the special role of federal authorities in planning the income and expenditures of the regional budget. Pinskaya \& Ziganshina (2015) discuss the need to build a new effective model of inter-budgetary interaction. Ilyin \& Povarova (2017) investigated the effect of the tax administration issues of big business in relation to revenues of regional governments.

Another part of the research is devoted to the analysis of regional budget revenues or expenditures (Zumakulova \& Tereshev, 2015; Povarova, 2016; Tokaev \& Basnukaev, 2016; Isaev, 2016; Khokhlova \& Ivanko, 2017; Ilyukhin, Ponomaryova \& Ilyukhina, 2017; Pechenskaya, 2018) or municipalities (Fayberg, 2015; Sumskaya, 2019). In our opinion, the approach based only on budget analysis is rather limited since the tax and budgetary system in Russia does not reflect the real potential of the regions in generating tax payments and the federal budget expenditures used in the territory.

In recent years, the financial system of the territory has been understood more broadly. For example, Marshalova (2005) considers the assessment of the financial flows of municipalities as the main level of value added formation. Klimanov,
Eremina \& Mihaylova (2018) use the features of the distribution of 'direct' federal budget expenditures to develop a balance of counter financial flows by region. However, these studies focus more on the theoretical aspect of the problem and do not offer methodological approaches to the assessment of financial balances.

Theoretically, the problem of financial balances of territories is considered by Sidorova \& Tatarkin (2012). This idea is further transformed into a design matrix of financial flows (Tatarkin, Sidorova \& Trynov, 2017). In spite of the high importance of these studies, the use of the matrix of financial flows is quite limited, as they are used only aggregated data from official sources.

In the international literature, the assessment of the influence of the public sector at the regional level is studied by statistical departments ${ }^{1}$ by identifying the added value formed at the level of regions and municipalities. The impact of state financial flows on the economic development of territories is considered, to a large extent, from the point of view of the effect of urbanization processes and an increase in the productivity of individual territories (Simmie\&Martin, 2010; Wang\&Turkina, 2020; Lobo, Bettencourt \& Strumsky, 2013; Lobo\&Smole, 2002; van Raan, van der Meulen \& Goedhart, 2016; Resende\&Cravo, 2014). Thus, today there is no generally accepted methodological approach to determining financial balances of the 'General Governance' sector at the territorial level.

\section{Methodology and data}

Our approach to the development and calculation of financial balances of the 'General Governance' sector is based on the principles of the international System of National Accounts (United Nations, 2009).

The essence of the proposed approach is the development of a system of accounts and balance ratios for open territorial units, conceptually and methodologically fully compatible with the UN SNA-2008 standard (for more on the theoretical and methodological aspects of the problem

U.S. Bureau of Economic Analysis (2006). Gross Domestic Product by State Estimation Methodology. Retrieved from: https://webcache.googleusercontent.com/search?q=cache:quOgPhQGmrkJ:https://www.bea.gov/sites/default/ files/methodologies/0417 GDP by State Methodology.pd$\mathrm{f}+\& \mathrm{~cd}=1 \& \mathrm{hl}=\mathrm{ru} \& \mathrm{ct}=\mathrm{clnk} \& \mathrm{gl}=\mathrm{ru} \& \mathrm{client}=$ opera $;$ EUROSTAT (2008). European Regional and Urban Statistics. Reference Guide. Retrieved from: https://ec.europa.eu/eurostat/ramon/ statmanuals/files/KS-RA-07-005-EN.pdf 
see the author's previous articles: Zakharchuk \& Pasynkov, 2017; Zakharchuk, Pasynkov, \& Trifonova, 2020).

Since this study aims to describe the financial flows of the public sector, first of all, it is necessary to bring the available statistical data into a form comparable to the SNA's methodology. To do this, the author has consolidated the data arrays in accordance with the accepted classification of income and expenditure of government bodies. From the SNA's perspective, the revenues of the 'General Governance' sector include the following payments to the budget system:

- Taxes on product and imports: value added tax (on goods sold and imported into the Russian Federation), excise taxes and tax on the extraction of minerals (rent);

- Other taxes on production: property tax, transport and land tax of enterprises as well as regular payments for the use of natural resources (except for the mineral extraction tax);

- Corporate income tax: in fact, according to the SNA classification, it is included in current taxes on income. However, to separate tax payments of corporations from households, we need a separate classification. This section includes the corporate income tax calculated in the given region of the Russian Federation as well as the corporate income tax of consolidated groups of taxpayers;

- Current taxes on income: households are included as property taxes, transport and land tax for individuals and taxes on total income of small businesses;

- Personal income tax: it is considered separately as a part of income taxes, due to its analytical value in determining the impact on the overall tax burden of the territory;

- Other sources of income: government duties and other payments unrelated to tax regulation.

At the next stage, it is necessary to determine the expenditures of budgets of all levels in the given territories in order to compile a general balance of the movement of funds in the sector.

First of all, it is necessary to distinguish between the concepts of 'total budget expenditures in the territory' and 'added value of the public sector', since a clear understanding of these terms is necessary for correct calculation of the expenditures of the 'General Governance' sector.

Value added of the public sector, according to the SNA's theoretical provisions, consists of salaries of employees (together with social charges) and other taxes on production and gross mixed income of the sector. In the corporate sector, gross mixed income plays a significant role in the formation of added value, since it includes both depreciation charges on fixed assets and the profit received by the sector. In Russia, in the corporate sector, mixed incomes make up about a half, in some sectors (e.g. mining), they can be $70-80 \%$ of the value added (Zakharchuk, 2019).

Since the 'General Governance' sector has peculiarities related to the redistributive nature of its flows, the sector does not actually have mixed incomes. This is due to the fact that no profit can be generated in public administration, since only non-profit organizations are included in it and depreciation payments are not refunded. As a result, the added value of the 'General Governance' sector includes practically only the costs of remuneration of employees with contributions to social funds. Consequently, when determining the costs of public administration on wages in the territory, it can rely on the data on the added value of the corresponding sections of the All-Russian Classifier of Economic Activities (OKVED), defining them as 'wages'. In the categories of OKVED-1 (valid until 2016), such sections include L, M, and N. According to OKVED-2, sections O (Public administration and military security; compulsory social security), $\mathrm{P}$ (Education), Q (Health care and provision of social services), $\mathrm{R}$ (Activities in the field of culture, sports, leisure and entertainment) belong to the 'General Governance' sector.

Another indicator that we need for calculations is the total expenditures of budgets of all levels in the territory, which reflects the costs of the 'General Governance' sector for all items of expenditure. To draw an analogy with the corporate sector, expenditures can be considered as 'intermediate consumption' and included in gross mixed income, for example, investments in fixed assets.

Therefore, there is a need to develop ways of calculating the costs of the 'General Governance' sector in the territory where information is provided by various information systems. The basis for calculating expenses is the information on the official website of the Treasury of Russia on the cash flow of the consolidated budgets of the regions (Form 0503323). The data are grouped according to the General Government Operations Classification Code (KOSGU), ranging from 211 'Wages' to 340 'Increases in Inventory Value'. In accordance with the requirements of the SNA, 
we reformatted and consolidated data from tables into a form comparable to national accounting. The KOSGU codes related to the added value of the 'General Governance' sector include the following:

1) The added value of the 'General Governance' sector, which includes direct budget expenditures for payments to employees, other payments, and charges on payments for wages. As a rule, these expenses belong to general administrative expenses for management and are displayed in Section O according to OKVED-2. The second part of the expenses included in this group is 'Subsidies to institutions' (241,242 KOSGU), which are essentially related to transfers. But they are in fact direct financing institutions performing public tasks of regions and municipalities in a given area. Of course, in the composition of this subsidy, not all costs are related to wages. We analyzed the 'Report on the Implementation of the Institution's Plan of its Economic Activities on Subsidies for the Fulfillment of the State (Municipal) Task' for 2017, which contains all the reported data for the Russian Federation for this type of activity. According to the Report, out of 742.43 billion rubles of funds allocated for the execution of state assignments, almost 507 billion or $68 \%$ were spent on paying wages, 206.31 billion rubles $(27.7 \%)$ were spent on the purchase of goods and services, and the rest of the expenses (4.3\%) are insignificant. Thus, the overwhelming part of the costs is reflected in the formation of the added value of territories by sections $\mathrm{P}, \mathrm{Q}, \mathrm{R}$ in the OKVED 2 system.

2) Transfers to the Households Sector. Social security (262.263 KOSGU) includes expenses on social support of the population outside the framework of the federal pension, social, and health insurance systems. The list of such expenses is quite wide, and it concerns both direct cash payments and compensations for various types of benefits (for example, travel expenses). In the SNA, such payments are classified as 'social security' and correspond to the income sector 'Households. The value added of the public sector is not included; it is allocated in a separate category.

3) Gross savings in the sector. This article includes information on the expenses of 310.330 KOSGU 'Capital investments.' These are funds aimed for construction of buildings and structures and for increasing the value of intangible assets.

4) Intermediate consumption of the sector 'General Governance'. According to KOSGU, it is the most diverse item for spending regional and municipal funds, it includes items from 221 (communication services) to 226 (other works, services) and 340 (an increase in the cost of inventories).

5) Other current transfers. The allocation of these payments into a separate class is dictated by the SNA concept, since in this case the expenditures of the general government sector do not have a subject link. This applies to both debt service (code 231 of KOSGU), which is a transfer to non-financial corporations. The same applies to interbudgetary transfers (code 251 of KOSGU), which refer to simple withdrawal of resources from the budget system.

As a result, in accordance with the proposed algorithm, we created a database on income and expenditures of the regions of the Ural Federal District for 2014-2018. The source of the data on revenues was the open data of the Federal Tax Service. The data on expenditures were taken from the official website of the Treasury of Russia and the value added tables.

\section{Results}

At the first stage, income matrices of the 'General Governance' sector were made for the regions of the Ural Federal District from 2014 to 2018 (the data for 2017 are shown in Table 1). In the whole federal district in this period, the growth of government revenues was $183 \%$, from $3,192.16$ billion to 5833.17 billion rubles. The weakest dynamics was shown by the growth of revenues from personal income tax, which increased on average by $31 \%$ over five years. The lowest growth rates of income from personal income tax were in the Khanty-Mansi Autonomous District and Kurgan region, and the highest, in Tyumen region, about 1.5 times. Revenues from other types of taxes grew evenly 1.6-1.7 times. The highest growth in revenues was from taxes on production and imports: the gross collection of payments increased by $92 \%$ (from $2,406,383.11$ to $4,610,758.87$ million rubles).

If we consider tax collection in the regions of the Ural Federal District, from 2014 to 2018, the most significant growth was shown by the Yamalo-Nenets Autonomous District and Tyumen region. The main source of tax payments in Yamal during this period was the corporate income tax (an increase from 57,939.7 to 133,247.8 million rubles, or 2.3 times), as well as taxes on production and imports (an increase from 569,521,0 to 
1,200,944.2 million rubles, or 2.1 times). In Tyumen region, taxes on production and imports increased even more, 2.6 times, due to an increase in value-added tax collections. Moreover, current taxes on household income increased significantly (by 160\%), which enabled the government to double tax payments in the region, from $163,870.6$ to 324,244.9 million rubles over 5 years.

The worst result in the development of its tax base was shown by Kurgan region, where the total flow of payments grew by only $27 \%$. The most significant growth was shown by other incomes - 2.2 times - as well as other taxes on production, which increased from 1,793.3 in 2014 to $2,871.6$ million rubles in 2018. Chelyabinsk and Sverdlovsk regions have the largest amounts of collected tax payments. Thus, corporate income tax in Chelyabinsk region from 2014 to 2018 increased by $246 \%$, while the overall growth in the Ural Federal District was only $172 \%$. Sverdlovsk region in this period demonstrated the most significant increase in receipts from other taxes on production: the whole federal district had a 1.72 times increase and Sverdlovsk region, 2 times.

The next step in calculating financial balances was the conversion of budgetary expenditures from KOSGU to the SNA and the distribution of spending by regions (Table 1 shows an example of such calculations for 2017). The results of the calculations showed that the expenditures of budgets related to value added vary considerably. While in the Yamalo-Nenets Autonomous District, the share of these costs is about $63 \%$, in Kurgan region it is less than $50 \%$. The average value of costs in value added in the Ural Federal District is $56.84 \%$, while the costs of Tyumen, Chelyabinsk and Sverdlovsk regions fluctuate with a half percent difference. This may indicate a certain standardized distribution of budgetary funds in the regions, allocated to the costs of paying salaries to public institutions. Moreover, the lower is the budgetary provision of the region, the lower is the share of such expenses, and vice versa.

Calculation of financial balances of the 'General Governance' sector by the regions

Table 1 of the Ural Federal District, 2017, mln rbs

\begin{tabular}{|c|c|c|c|c|c|c|}
\hline & $\begin{array}{l}\text { Kurgan } \\
\text { Region }\end{array}$ & $\begin{array}{c}\text { Sverdlovsk } \\
\text { Region }\end{array}$ & $\begin{array}{l}\text { Tyumen } \\
\text { Region }\end{array}$ & $\begin{array}{c}\text { Chelyabinsk } \\
\text { Region }\end{array}$ & $\begin{array}{c}\text { KhMAO - } \\
\text { Yugra }\end{array}$ & $\begin{array}{c}\text { Yamalo-Nenets } \\
\text { Autonomous } \\
\text { District }\end{array}$ \\
\hline \multicolumn{7}{|c|}{ INCOME } \\
\hline Taxes on production and imports & $10,343.3$ & $87,443.3$ & $123,729.7$ & $69,768.6$ & $1,981,107.9$ & $934,620.9$ \\
\hline Other taxes on production & $2,504.1$ & $32,770.5$ & $11,265.4$ & $17,573.4$ & $63,236.5$ & $65,230.8$ \\
\hline Corporate income tax & $4,856.6$ & $82,518.6$ & $54,028.4$ & $52,208.0$ & $81,747.2$ & $87,274.5$ \\
\hline Current taxes on household income & $2,391.1$ & $18,057.9$ & $5,869.3$ & $11,703.9$ & $7,513.4$ & $2,597.3$ \\
\hline Tax on personal income & $9,268.3$ & $89,897.7$ & $31,271.2$ & $58,440.1$ & $79,629.0$ & $50,443.9$ \\
\hline Other revenues & 433.1 & $1,448.6$ & 586.7 & $4,261.3$ & 673.3 & 562.0 \\
\hline TOTAL INCOME & $29,796.4$ & $312,136.6$ & $226,750.7$ & $213,955.3$ & $2,213,907.2$ & $1,140,729.4$ \\
\hline \multicolumn{7}{|c|}{ EXPENDITURES } \\
\hline \multicolumn{7}{|l|}{ Consolidated regional budget } \\
\hline Added value of the sector & $20,313.1$ & $147,884.9$ & $90,345.6$ & $95,622.4$ & $147,800.3$ & $105,972.2$ \\
\hline Transfers to the Households Sector & $10,797.5$ & $54,412.5$ & $18,597.5$ & $37,807.9$ & $31,087.1$ & $21,478.8$ \\
\hline Gross savings & $2,812.8$ & $17,603.6$ & $25,145.5$ & $10,042.2$ & $18,040.0$ & $13,630.8$ \\
\hline Intermediate consumption of the sector & $6,752.4$ & $36,305.0$ & $18,318.9$ & $25,616.8$ & $31,301.7$ & $19,562.3$ \\
\hline Other current transfers & $1,289.3$ & $5,420.4$ & $7,616.1$ & 961.7 & $16,312.3$ & $7,609.0$ \\
\hline Total & $41,965.1$ & $261,626.5$ & $160,023.6$ & $170,051.0$ & $244,541.4$ & $168,253.1$ \\
\hline \multicolumn{7}{|l|}{ Federal budget of the Russian Federation } \\
\hline Added value of the sector & $19,860.5$ & $92,076.7$ & $32,181.1$ & $66,205.4$ & $27,756.1$ & $14,638.5$ \\
\hline Gross savings & $1,527.7$ & $7,082.8$ & $2,475.5$ & $5,092.7$ & $2,135.1$ & $1,126.0$ \\
\hline Intermediate consumption of the sector & $8,249.8$ & $38,247.2$ & $13,367.5$ & $27,500.7$ & $11,529.5$ & $6,080.6$ \\
\hline Other current transfers & 916.6 & $4,249.7$ & $1,485.3$ & $3,055.6$ & $1,281.1$ & 675.6 \\
\hline Total & $30,554.7$ & $141,656.5$ & $49,509.4$ & $101,854.4$ & $42,701.7$ & $22,520.8$ \\
\hline TOTAL EXPENDITURES & $72,519.7$ & $403,282.9$ & $209,533.0$ & $271,905.4$ & $287,243.2$ & $190,773.8$ \\
\hline Net lending borrowing of the sector & $-42,723.3$ & $-91,146.3$ & $17,217.7$ & $-57,950.1$ & $1,926,664.1$ & $949,955.5$ \\
\hline
\end{tabular}


Another factor that reduces the share of wages in the budget can be the higher social security costs. Thus, Kurgan region is the leader in terms of spending on transfers to the "Households" sector; more than a quarter of all expenses $(25.73 \%)$ were spent for these purposes. The lowest costs in this area are observed in Tyumen region (only 11.62\%); in Sverdlovsk and Chelyabinsk regions, social assistance costs are approximately equal (20-22\%); oil and gas producing regions are the same in relative spending on social protection of the population (12.71-12.77\%). In general, in the Ural Federal District, 174.18 billion rubles were allocated to social protection in 2017 or $16.6 \%$ of all expenses across the territory.

The study of regional expenditures on capital construction did not reveal any regularities in the structure of financial balances. The smallest share of expenses is in Chelyabinsk region (5.91\%); in Kurgan, Sverdlovsk regions, Khanty-Mansiysk and Yamalo-Nenets Autonomous District, this indicator is around $6.7-8.1 \%$. The leader in terms of capital investments from the budget is Tyumen Region, which allocated 25.15 billion rubles to investments or $15.71 \%$ of total expenses. Thus, expenditures on capital construction are determined by the challenges that the regions face and not by financial opportunities.

In general, the budgets of the regions and municipalities of the Ural Federal District spent 1,046.46 billion rubles. Despite the significant lack of their own financial resources, the biggest budget in 2017 was in Sverdlovsk region. The poorest region in terms of budget expenditures was Kurgan region. Comparing tax revenues and expenditures of the consolidated budgets of the regions of the Ural Federal District, we can see that in almost all regions (except for Kurgan region) income from the economy exceeds expenditures. However, after calculating the contribution of the federal part to the added value of each region of the Ural Federal District (Table 2), it can be seen that the situation has changed a lot. The most significant federal expenditures were in Kurgan region, they amount to 19.86 billion rubles or $9.89 \%$ of the region's gross value added. Sverdlovsk, Chelyabinsk and Tyumen regions depend on federal revenues for 3-5\% of their GRP, and the Khanty-Mansi Autonomous District and Yamalo-Nenets Autonomous District have minimal significant funding from the federal budget - less than $1 \%$.

At the same time, as we have already noted, the financial balance in the 'General Governance' sector consists of both the value added costs of the sector (mainly salaries) and other expenses. If, according to the consolidated budget of the region, the sums of expenditures on investments, social security, purchase of goods and services were calculated by using the 'direct' method, then the federal budget expenditures for these purposes can be determined only indirectly. The official website of the Federal Treasury of the Russian Federation contains only fragmentary information on the structure of financing of federal budgetary institutions. Based on these data, when calculating the total costs of the federal budget in the regions, it was decided, very tentatively, to assume that the proportions of the costs are as follows: $65 \%$ - costs of wages and social charges; $27 \%$ - purchase of goods, works and services; $5 \%$ - investments; and 3\% - other expenses.

In accordance with this distribution, the financial balances of the 'General Governance' sector were compiled by region for 2017 (Table 1). It can be seen that if we take into account direct federal costs in regions of the Ural Federal District,

Table 2

Calculation of the value added of the federal part of expenditures in GRP of the regions of the Ural Federal District, 2017, mln rbs and \%

\begin{tabular}{|l|r|r|r|r|r|}
\hline $\begin{array}{c}\text { Regions of the Ural Federal } \\
\text { District }\end{array}$ & $\begin{array}{c}\text { Gross regional } \\
\text { product }\end{array}$ & $\begin{array}{c}\text { Added value of the } \\
\text { sector 'General } \\
\text { Governance' }\end{array}$ & $\begin{array}{c}\text { Regional } \\
\text { consolidated budget } \\
\text { expenditures }\end{array}$ & $\begin{array}{c}\text { Federal budget } \\
\text { expenditures }\end{array}$ & $\begin{array}{c}\text { Federal } \\
\text { expenditures } \\
\text { as\% of GRP }\end{array}$ \\
\hline Kurgan Region & $200,868.2$ & $40,173.6$ & $20,313.1$ & $19,860.5$ & 9.89 \\
\hline Sverdlovsk Region & $2,142,514.3$ & $239,961.6$ & $147,884.9$ & $92,076.7$ & 4.30 \\
\hline KhMAO - Yugra & $3,511,127.5$ & $175,556.4$ & $147,800.3$ & $27,756.1$ & 0.79 \\
\hline $\begin{array}{l}\text { Yamalo-Nenets Autonomous } \\
\text { Okrug }\end{array}$ & $2,461,442.8$ & $120,610.7$ & $105,972.2$ & $14,638.5$ & \\
\hline Tyumen Region & $1,013,424.5$ & $87,154.5$ & $54,973.4$ & $32,181.1$ & \\
\hline Chelyabinsk Region & $1,348,564.7$ & $161,827.8$ & 3.18 \\
\hline \multicolumn{1}{|c|}{ Total } & $10,677,942.0$ & $825,284.6$ & $572,566.3$ & $252,718.3$ & \\
\hline
\end{tabular}

The author's calculations based on the data of Rosstat and the Ministry of Finance 
then only Tyumen region with national districts can claim to be 'self-sufficient' enough. Kurgan region is the most dependent on external financing through all budgetary channels: in this region, the expenses were more than twice the level of tax payments. Sverdlovsk and Chelyabinsk regions show a lack of their own tax base, the former amount to a little more than 91 billion rubles, and the latter, almost 58 billion rubles. At the same time, if we compare net lending / borrowing in relation to the sector's income, it turns out that the indicators are practically equal, about $27-29 \%$. Tyumen region, the only one of all the regions of the Ural Federal District, has an equal amount of income and expenses. Finally, the autonomous districts demonstrate an impressive financial redundancy of the budget system; out of 2,213.91 billion rubles of taxes transferred in the Khanty-Mansiysk district, only 287.24 billion rubles were used at all levels of the budget system in the territory, or only $13 \%$. The situation is similar in the Yamalo-Nenets Autonomous District - 1,140.72 billion rubles were received, 190.77 billion rubles were spent, that is, $83.3 \%$ of taxes remained in the federal budget. In general, in the Ural Federal District, tax and other payments of over 2,702 billion rubles were transferred to the federal budget in 2017.

\section{Conclusion}

The study on the development of financial balances of the Ural Federal District led us to the following basic conclusions:

1. The development of the account 'General Governance' at the regional level allows us to more accurately determine the directions of transfer and spending of funds on all levels in the territory. This can contribute to the development of a methodology for assessing the 'interregional' movement of financial resources.
2. The calculation of the federal part of expenditures in a given region, in the absence of reliable data, can be carried out by deducting the regional budget expenditures from the added value of the region. The problem of including activities in the public sector involving commercial companies can be solved depending on the specifics of the region and additional calculations. The problem of including activities in the public sector with the presence of commercial companies will vary depending on the specifics of the region, but this can be eliminated by additional calculations.

3. Financial balances of each region of the Ural Federal District have their own characteristics. The oil and gas regions - the Khanty-Mansi and Yamalo-Nenets Autonomous Districts - are net donors of the 'General Governance' sector, while Kurgan region, on the contrary, is a recipient. Tyumen region, due to the redirection of a part of the financial resources of the autonomous districts, has practically zero net lending/borrowing. Industrialized Sverdlovsk and Chelyabinsk regions cannot provide themselves with financial resources due to the high federal budget expenditures in the territories.

4. The expenditures of the 'General Governance' sector have a significant impact on the formation of added value in non-oil and gas regions of the Ural Federal District. Even if we don't take into account the influence of the intermediate consumption of the sector, it can be determined that public administration accounts for more than $10 \%$ of GRP of Chelyabinsk and Sverdlovsk regions and more than $20 \%$ of Kurgan region.

In conclusion, it should be noted that this study is a part of long-term research to compile full-fledged financial balances at the territorial level, since specification of all financial flows is a fairly ambitious task.

\section{References}

Bogolib, T.M. (2015). Community budget in the system of inter-budgetary relations. ScienceRise, 7(3), 6-12. doi: 10.15587/2313-8416.2015.46592

Fayberg, T.V. (2015). Problems and prospects of tax revenues of local budgets in the Russian Federation. Taxes and Financial Law, 10, 141-148.

Ilyin, V.A., \& Povarova, A.I. (2017). Failures in Big Business Tax Administration and Their Impact on Regional Budgets. Economy of Region, 13(1), 25-37. doi: 10.17059/2017-1-3

Ilyukhin, A.A., Ponomaryova, S.I., \& Ilyukhina, S.V. (2017). Macroeconomic Analysis of Sverdlovsk Oblast Budget Forecast in the Context of Economic Growth in Russia. The Manager, 6(70), 72-79.

Isaev, A.G. (2016). Distribution of financial resources within the budget system of the Russian Federation and regions' economic growth. Spatial Economics, 4, 61-74. doi: 10.14530/se.2016.4.061-074 
Istomina, N.A. (2016). Impact of the state financial decisions on budgetary planning in the constituent entities of the Russian Federation. Bulletin of Irkutsk State Economics Academy, 2, 250-257. doi: 10.17150/1993-3541.2016.26(2).250-257

Khapsaeva, R.B. (2014). Theoretical aspects of formation of budget expenditures in the region. Fundamental Research, 12, 1267-1269.

Khokhlova, N.S., \& Ivanko, G.V. (2017). Asymmetry in the System of State Management of Revenues and Expenditures of Budgets. Bulletin of Baikal State University, 27(3), 380-388. doi: $\underline{10.17150 / 2500-2759.2017 .27(3) \cdot 380-388}$

Klimanov, V.V., Eremina, D.A., \& Mihaylova, A.A. (2018). Analysis of the Balance of Financial Flows between the Center and Regions in the Russian Federation. ECO Journal, 48(9), 51-62. doi: 10.30680/ECO0131-7652-2018-9-51-62

Lobo, J., \& Smole, D. (2002). Stratification and spatial segregation of human capital as determinants of metropolitan productivity in the United States. Urban Studies, 39(3), 529-547. doi: $\underline{10.1080 / 00420980220112810}$

Lobo, J., Bettencourt, L., \& Strumsky, D. (2013).West GB Urban Scaling and the Production Function for Cities. PLoS ONE, 8(3), 1-10. doi: 10.1371/journal.pone.0058407

Marshalova, A.S. (2005). Formation of financial flows when developing a strategy for the development of municipalities. Region: Economics and Sociology, 3, 163-175.

Pechenskaya, M.A. (2018). Improvement of personal income tax formation and distribution process in the budget system of Russia (In the case study of muncipal budgets). Perm University Herald. Economy, 13(4), 589-601. doi: 10.17072/1994- 9960-2018-4-589-601

Pinskaya, M.R., \& Ziganshina, L.A. (2015) Balancing regional and local budgets: problems and solutions. Innovative Development of Economy, 6, 90-98.

Povarova, A.I. (2016). Problems and Specific Features of Sub-Federal Budgets Execution in 2015. Economic and Social Changes: Facts, Trends, Forecast, 4, 144-164. doi: 10.15838/esc/2016.4.46.8

Povarova, A.I. (2016). Regional budget-2016: priorities do not change. Economic and Social Changes: Facts, Trends, Forecast, 2, 133-152. doi: 10.15838/esc.2016.2.44.8.

Resende, G., \& Cravo, T. (2014). What about regions in regional science? A convergence exercise using different geographic scales of European Union. Economics Bulletin, 34, 1381-1395.

Sidorova, E.N., \& Tatarkin, D.A. (2012).Optimization of the regions' financial flows as a factor in improving their security. Economy of Region, 2, 94-105. doi: 10.17059/2012-2-8

Simmie, J., \& Martin, R. (2010) The economic resilience of regions: towards an evolutionary approach. Cambridge Journal of Region's Economy and Society, 3(1), 27-43. doi: 10.1093/cjres/rsp029

Sumskaya, T.V. (2019). The main aspects of formation of localself-governments' budgets in the Russian Federation. Vestnik NSUEM, 19(2), 99-115. doi: 10.25205/2542-0429-2019-19-2-99-115

Tatarkin, D.A., Sidorova, E.N., \& Trynov A.V. (2017). Simulation of structural changes in the regions economy based on the matrix of financial flows. Economic and Social Changes: Facts, Trends, Forecast, 1(10), 218-234. doi: 10.15838/esc.2017.1.49.12

Tokaev, N.K., \& Basnukaev, M.S. (2016). Regional self-sufficiency: challenges and solutions. Finance: Theory and Practice, 20(4), 17-21. doi: 10.26794/2587-5671-2016-20-4-17-21

United Nations, the European Commission, the International Monetary Fund, the Organisation for Economic Cooperation and Development, and the World Bank (2009). SNA - System of National Accounts 2008, New York.

van Raan, A., van der Meulen, G., \& Goedhart, W. (2016) Urban Scaling of Cities in the Netherlands. PLoS ONE, 11(1), 1-16. doi: 10.1371/journal.pone.0146775

Wang, Y.H., \& Turkina, E. (2020) Economic complexity, product space network and Quebec's global competitiveness. Canadian Journal of Administrative Sciences, 37(3), 334-349. doi: 10.1002/ cjas. 1555 
Zakharchuk, E.A., \& Pasynkov, A.F. (2017). Regional Balance Model of Financial Flows through Sectoral Approaches System of National Accounts. Economy of Region, 13(1), 318-330. doi: $\underline{10.17059 / 2017-1-28}$

Zakharchuk, E.A. (2019). Spatial Structure of the Formation of Value Added in the Arctic Territories. Economy of Region, 15(2), 391-408. doi: 10.17059/2019-2-7

Zakharchuk, E.A., Pasynkov, A.F., \& Trifonova, P.S. (2020) The role of budget and tax policy in the formation of financial balances of regions on the example of the Ural Federal District. Economics, Taxes \& Law, 13(1), 86-98. doi: 10.26794/1999-849X-2020-13-1-86-98

Zhuravleva, T.A. (2015). Role of taxes in formation of the budgetary provision of subjects of the Russian Federation. Regional Economy. The South of Russia, 2, 11-17.

Zumakulova, F.S., \& Tereshev, M.A. (2015). Consolidated budgets of subjects of Russian Federation: analysis of acuestss and charges. Science Almanac, 11-1(13), 230-236. doi: 10.17117/ na.2015.11.01.230

\section{Information about the author}

Alexey F. Pasynkov - Cand.Sc. (Economics), associate professor, senior researcher, Institute of Economics of the Ural Branch of the Russian Academy of Sciences (29, Moskovskaya str., Ekaterinburg, 620014, Russia); e-mail: monografia@mail.ru

ARTICLE INFO: received September 15, 2020; accepted December 1, 2020

\section{Информация об авторе}

Пасынков Алексей Федорович - кандидат экономических наук, доцент, старший научный сотрудник Института экономики Уральского отделения Российской академии наук (620014, Россия, г. Екатеринбург, ул. Московская, 29); e-mail: monografia@mail.ru

ИНФОРМАЦИЯ О СТАТЬЕ: дата поступления 15 сентября 2020 г.; дата принятия к печати 1 декабря 2020 г. 